\title{
Spawning Behavior and Egg Development of Aplysia kurodai Inhabiting the Coastal Waters of Jeju Island, Korea
}

\author{
Chi-Hoon Lee ${ }^{1}$, Bong-Kiun Kaang ${ }^{2}$, and ${ }^{\dagger}$ Young-Don Lee ${ }^{1}$ \\ ${ }^{1}$ Marine Science Institute, Jeju National University, Jeju 695-965, Republic of Korea \\ ${ }^{2}$ Department of Biological Sciences, College of National Sciences, Seoul National University, \\ Seoul 151-747, Republic of Korea
}

\begin{abstract}
This study was investigated spawning behavior, structure of egg masses and egg development in Aplysia kurodai inhabiting the coastal waters of Jeju Island, Korea. The mating and courtship behavior of $A$. kurodai occurred in the form of unilateral copulating with chain formation. In chain copulation, only the first animal acted as a female; the second and succeeding animals acted as males (sperm donors) to the animals in front and as females to the animals behind. The fertilized eggs were packaged in capsules that are embedded in jelly to form a cylindrical string called an egg masses. The number of capsule per $\mathrm{cm}$ of the egg masses was 55 to 60 capsules and each capsule within the egg masses held 15 to 25 eggs. After spawning, the egg masses were bright yellow or orange in color. This egg masses color not changed until embryos developed into trochophore stage. Thereafter, as embryo developed from trochophore stage to veliger stage the egg masses color became brownish. The fertilized eggs were spherical, with a diameter of approximately $80 \pm 1 \mu \mathrm{m}$ at spawning. At 5 to 6 days after spawning, the embryo developed into trochophore stage and began to rotate within the egg capsule. In the trochophore stage, the precursor of the velum, called the prototroch or prevelum, developed. At 10 days after spawning, the prevelum is transformed into the velum, and the trochophore developed into veliger stage. Between 10 to 15 days after spawning, the veligers broke out of the egg capsule, and hatched as free-swimming larvae.
\end{abstract}

Key words : Spawning behavior, Aplysia kurodai, Egg mass, Trochophore, Veliger

\section{INTRODUCTION}

Although most gastropods exhibit gonochorism, some species such as opithobranchia and pulmonatea generally are functional simultaneous hermaphrodites. In simultaneous hermaphrodites, the reproductive systems are composed of form a single gonad, i.e., the ovotestis and a common genital gonoduct (Hadfield \& Switzer-Dunlap, 1984; Painter et al., 1985; Berry et al., 1992; Kress \& Schmekel, 1992;
Klussmann-Kolb, 2004). These animals simultaneously produce eggs and sperm but do not normally self-fertilize; they cross-fertilization by copulation with another individual's sperm (Hadfield \& Switzer-Dunlap, 1984). The role of the male induces the production and transfer of autosperm (own sperm), and the role of the female includes the storage of allosperm (another animal of sperm) and production of a gelatinous egg mass (Beeman, 1970; Hadfield \& Switzer-Dunlap, 1984; Carefoot, 1987). Thus, opisthobranchs

\footnotetext{
Manuscript received 3 January 2014, Received in revised form 22 January 2014, Accepted 2 February 2014

${ }^{\dagger}$ Corresponding Author : Young-Don Lee, Marine Science Institute, Jeju National University, 19-5, Hamdeok 5-gil, Jocheon-eup, Jeju-si 695-965, Jeju Special Self-Governing Province, Republic of Korea. Tel. : +82-64-782-8922, Fax : +82-64-783-6066, E-mail : leemri@ jejunu.ac.kr

This is an Open Access article distributed under the terms of the Creative Commons Attribution Non-Commercial License (http:// creativecommons.org/licenses/by-nc/3.0) which permits unrestricted non-commercial use, distribution, and reproduction in any medium, provided the original work is properly cited.
} 
have evolved different male and female structures during copulation. The types of copulation in opisthobranchs differ into reciprocal or unilateral according to facing direction (Lalli \& Conver, 1973; Rivest, 1984).

Many gastropod species in the intertidal zone enclose their fertilized eggs within capsular or gelatinous egg masses to provide protection against extreme changes in the surrounding environment, such as desiccation, temperature, salinity, ultraviolet radiation and water flow (Pawlings, 1999; Przeslawski, 2004; Przeslawski \& Benkendorff, 2005).

The encapsulation of fertilized eggs is a common phenolmenon among many marine invertebrate groups, and the structure and composition of egg masses differ among species (Przeslawski, 2004). Capsulated egg masses are found in the neritoposina and some caenogastropda, and gelatinous egg masses are found in the heterobranchia (Przeslawski, 2004). The capsulated egg masses of many caenogastropods consist of multiple distinct capsules often connected to one another by a common basal layer (Benkendorff, 1999). The gelatinous egg masses consist of a jelly matrix in which many eggs are embedded, and a microscopic vitelline capsule surrounds each egg or a small group of eggs (Eyster, 1986). The shapes and sizes of egg capsules vary among species, ranging from flat hemispherical disks to tall erect vases, and spanning a size range from millimeters to centimeters in length. Despite the widespread occurrence of these egg coverings, little is known about the precise morphological and physiological consequences of depositing embryos within these benthic egg capsules and gelatinous egg masses.

The genus Aplysia, also known as sea hares, belongs to the subclass opisthobranchia and has 50 species that are distributed worldwide and graze mainly in the tidal and subtidal zones (Beeman, 1968; Klussmann-Kolb, 2004). Since Aplysia have a relatively simple nervous system with many large neurons, they have been of a major interest to neurobiologists and physiologists (Kandel, 1979; Kaang, 1993). Studies of several aplysiid species in various locales around the world have provided information on reproduction (Yusa, 1996; Lee et al., 2011), metamorphosis (Kriegstein et al., 1974; Kempf, 1981), growth, fecundity, and seasonal abundance (Strenth \& Blankenship, 1991; Plaut, 1993), but little is known about reproductive characteristics and embryogenesis within egg masses of Aplysia kurodai. This study was investigated spawning behavior, structure of egg masses and egg development in order to provide information on reproductive biology of A. kurodai inhabiting the coastal waters of Jeju Island, Korea.

\section{MATERIALS AND METHODS}

Adult A. kurodai were collected in the intertidal zone along the coastal waters of the Hamduk, northeast of Jeju Island, Korea. Adult animals were kept at the Marine Science Institute, Jeju National University, Jeju, Korea, in 5 ton aquaria with an open seawater circulation system, and fed daily fresh algae (Ulva sp.). Newly spawned egg clusters were collected from the aquaria, rinsed, and inserted into 1-L flasks containing filtered seawater (filter holes diameter $0.45 \mu \mathrm{m})$ under continuous aeration. The filtered seawater was changed daily and was maintained at room temperature $\left(20 \pm 0.5^{\circ} \mathrm{C}\right)$ and salinity $(31.9 \pm 0.6 \mathrm{PSU})$. The structure of egg mass and egg development $\mathrm{t}$ of A. kurodai were viewed with a Leica DMR optical microscope.

\section{RESULTS}

\section{Reproductive behavior and spawning charac-} teristics

A. kurodai produced fertilized egg by internal fertilezation via copulation. Unilateral copulation occurred in $A$. kurodai, i.e., both animals of a pair facing in the same direction. When a pair of A. kurodai copulated, the first animal (A) attaching to the substrate acted as a female, and the second animal (B) that is in close contact with the dorsal surfaces of A acted as a male. Then, B protruded 

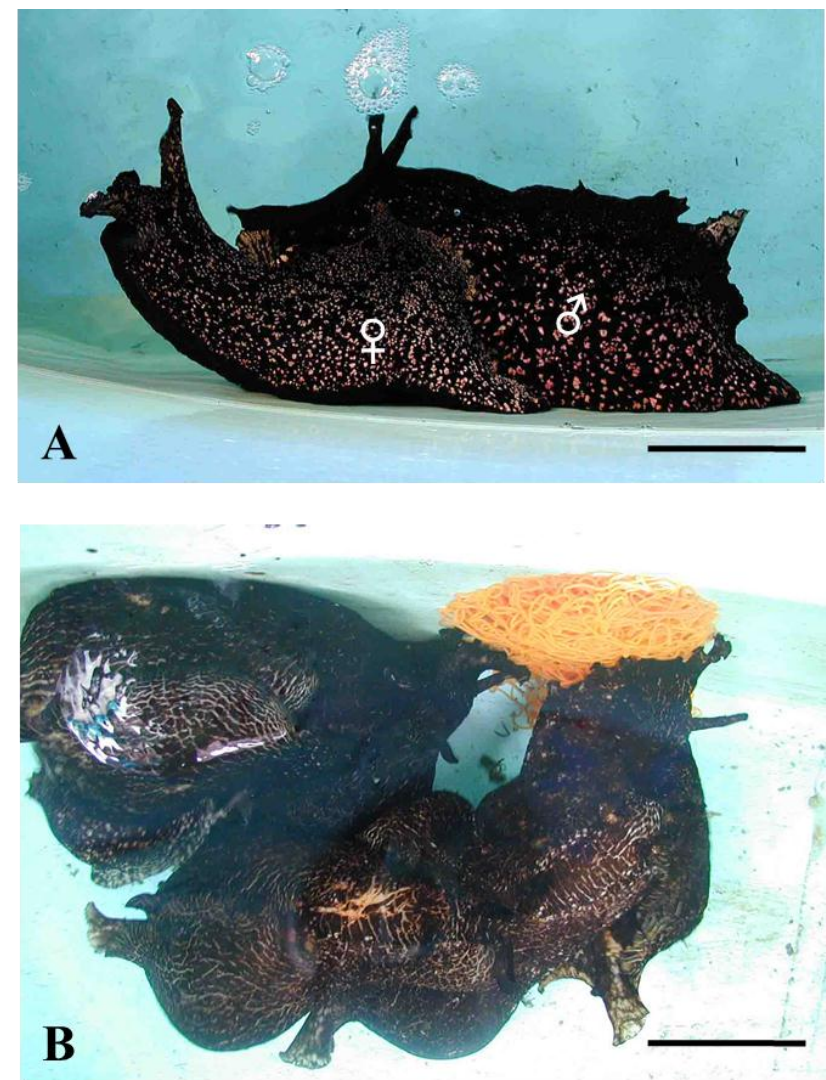

Fig. 1. Copulation and egg masses of Aplysia kurodai in rearing tank. (A) copulation a pair of Aplysia kurodai. (B) formation of coupling chain. Scale bars indicate $10.0 \mathrm{~cm}$.

penis and inserted it into the common genital aperture of $\mathrm{A}$ and sperm is released (Fig. 1A). Frequently, if the other animals join the initial copulating pair, a coupling chain is formed and only the first animal acted as a female, deposited egg string on the walls of the rearing tank (Fig. 1B).

\section{Morphological feature egg mass}

The fertilized eggs were packaged in capsules that are embedded in jelly to form a cylindrical string called an egg masses (Fig. 2A). The number of capsule per $\mathrm{cm}$ of the egg masses was 55 to 60 capsules and each capsule within the egg masses held 15 to 25 eggs (Fig. 2B, C).

After spawning, the egg masses were bright yellow or orange in color (Fig. 3A). This egg masses color not changed until embryos developed into trochophore stage (Fig. 3B).
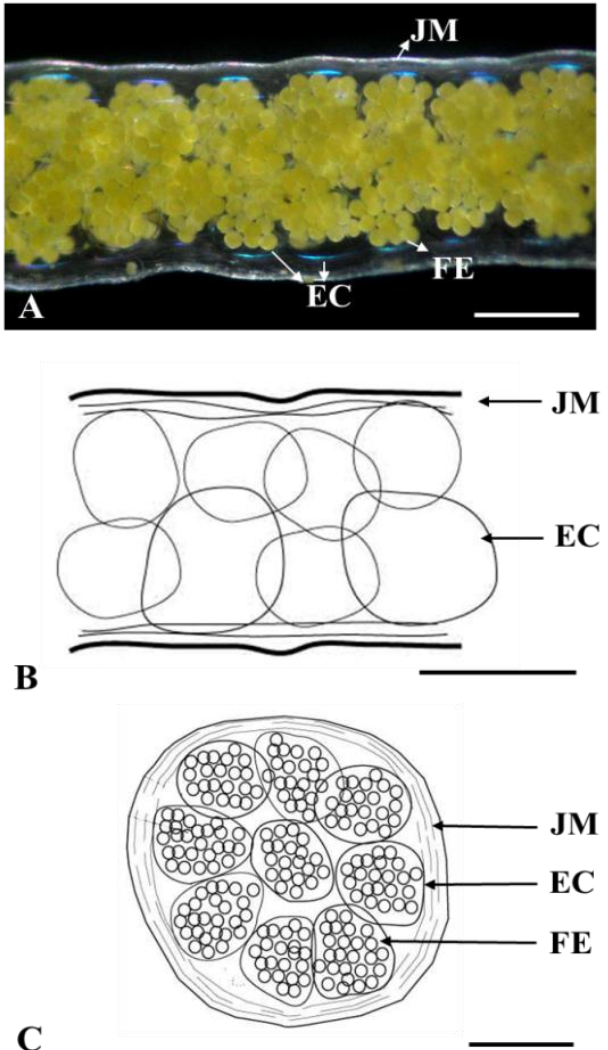

Fig. 2. Egg masses of Aplysia kurodai. (A) morphological feature of egg masses. (B) and (C) schematic outlines of egg masses. FE, fertilized egg; Ec, egg capsule; JM, Jelly metrix. Scale bars indicate $500 \mu \mathrm{m}$.
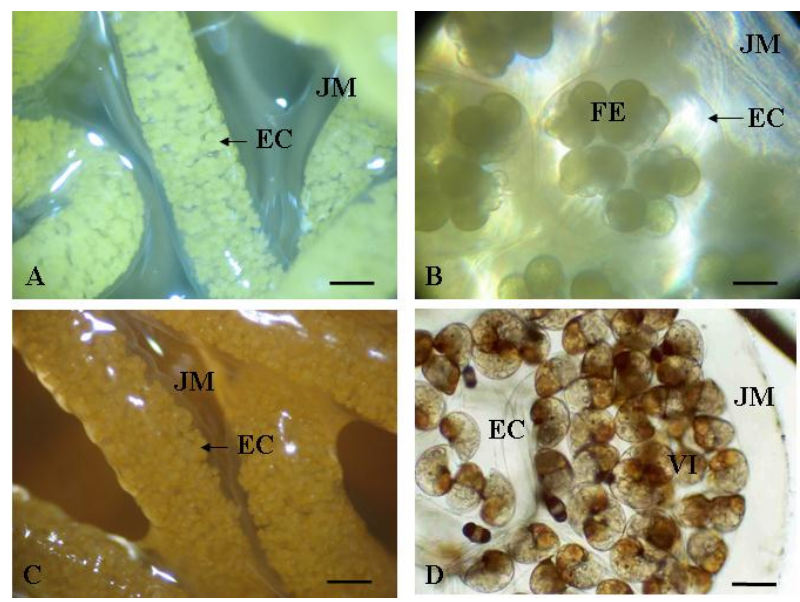

Fig. 3. Change of egg masses in color according to developmental stage. (A) and (B) egg masses just after spawning. (C) and (D) egg masses of 10 days after spawning. FE, fertilized egg; EC, egg capsule; JM, jelly matrix; VI, veliger. Scale bars indicate 200 $\mu \mathrm{m}(\mathrm{A}$ and $\mathrm{C})$ and $100 \mu \mathrm{m}(\mathrm{B}$ and $\mathrm{D})$. 
Thereafter, as embryo developed from trochophore stage to veliger stage the egg masses color became brownish (Fig. 3C, D).

\section{Embryogenesis}

The fertilized eggs were spherical, with a diameter of approximately $80 \pm 1 \mu \mathrm{m}$ at spawning (Fig. 4A). The cell division underwent unequal spiral cleavage. The first cleavage passed through opposite poles of the embryo and split it into two unequal blastomeres and the formation of a compact 2-cell embryo took about $12 \mathrm{hr}$ after spawning (Fig. 4B). In the second cleavage, the cleavage of the two blastomeres were not synchronous; that of the smaller blastomere occurred at $5 \mathrm{hr}$ after the formation of 2-cell embryo and that of the larger one occurred $1 \mathrm{hr}$ later (Fig. 4C). Thereafter, formation of a compact 4-cell embryo took about $18 \mathrm{hr}$ after spawning (Fig. 4D). The third cleavage
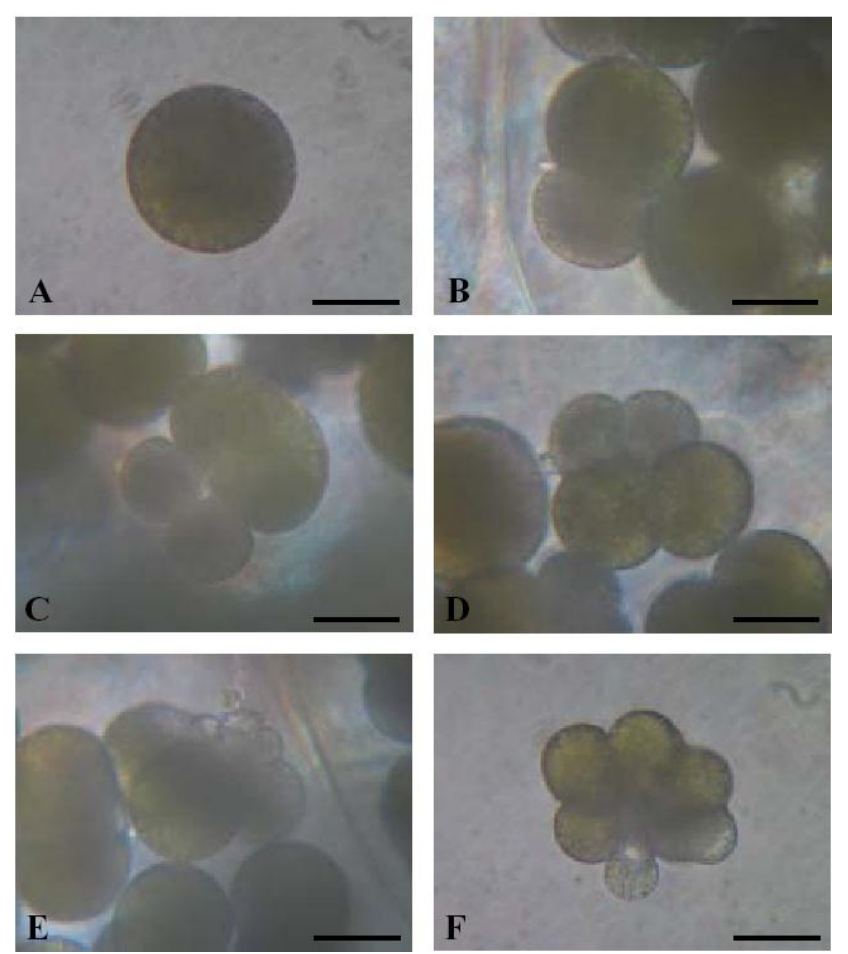

Fig. 4. Early developmental stage of Aplysia kurodai at $20.0 \pm 0.5^{\circ} \mathrm{C}$ and $31.9 \pm 0.6 \mathrm{PSU}$ in the laboratory. (A) fertilized egg, (B) 2-cell stage, (C) beginning of 4-cell stage, (D) 4-cell stage, (E) 8-cell stage, (F) 16-cell stage. Scale bars indicate $50 \mu \mathrm{m}$. occurred spirally, and the four small blastomeres were divided from the animal pole of each large blasto-meres. These small blastomeres called the first quartet. The formation a compact 8-cell embryo occurred at $6 \mathrm{hr}$ after the formation of 4-cell embryo and took about $24 \mathrm{hr}$ after spawning (Fig. 4E). The fourth cleavage occurred in a counterclockwise direction, and the four large blastomeres divided into four small blastomers, which called the second quartet. The first quartet also divided into four small blastomers. The formation a compact 16-cell embryo occurred at $7 \mathrm{hr}$ after the formation of 8-cell embryo and took about $31 \mathrm{hr}$ after spawning (Fig. 4F).

At 5 to 6 days after spawning, the embryo developed into trochophore stage and began to rotate within the egg capsule (Fig. 5A). In the trochophore stage, the precursor of the velum, called the prototroch or prevelum, developed. At 10 days after spawning, the prevelum is transformed into the velum, and the trochophore developed into veliger stage (Fig. 5B). Between 10 to 15 days after spawning, the veligers broke out of the egg capsule, and hatched as freeswimming larvae (Fig. 5C, D).
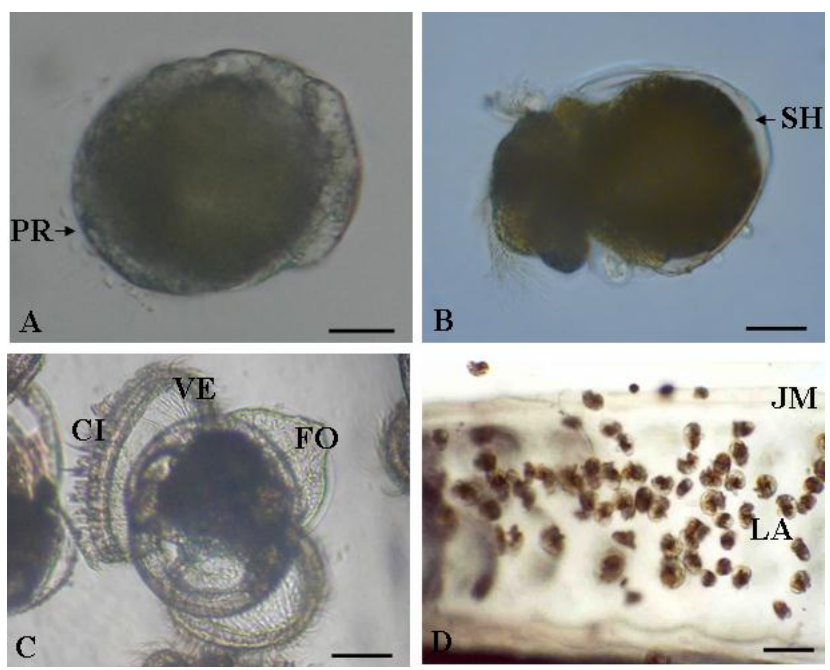

Fig. 5. Early developmental stage of Aplysia kurodai. (A) trochophore stage. (B) veliger stage. (C) and (D) hatching larvae. CI, cilia; FO, foot; JM, jelly matrix; LA; larva; PR, prevelum; SH, shell; VE, velum. Scale bars indicate $20 \mu \mathrm{m}$ (A to C) and $500 \mu \mathrm{m}$ (D). 


\section{DISCUSSION}

Most opisthobranchs, including aplysiid, are sitmultaneous hermaphrodites, i.e., an adult animal has both a functional female as well as a male reproductive system, and lay egg masses by internal cross-fertilization through copulation (Hadfield \& Switzer-Dunlap, 1984). The types of copulation in opisthobranchs differ into reciprocal or unilateral according to facing direction. Reciprocal copulation involves two animals facing in opposite directions and the penis is inserted into the common genital aperture of each other and exchanged sperm. This method of copulation occurs mainly in gymnosomata (Paedoclione doliiformis; Lalli \& Conover, 1973), nudibranchs (Tenellia pallida; Eyster, 1979), notaspideans and sacolossans (Hadfiedl \& Switzer-Dunlap, 1984). The unilateral copulation occurs mainly in cephalaspidea (Navanax inermis; Leonard \& Lukowiak, 1991) and anaspidea (Aplysia spp.; Kandel, 1979, Yusa, 1996), and often, if more than two animals are available, a coupling chain is formed. However, reciprocal copulation also occurs in Phyllaplysia taylori (Beeman, 1970) and A. brasiliana (Blankenship et al., 1983). In this study, the mating and courtship behavior of A. kurodai occurred in the form of unilateral copulating with chain formation. In chain copulation, only the first animal acted as a female; the second and succeeding animals acted as males (sperm donors) to the animals in front and as females to the animals behind.

The encapsulation of eggs within benthic egg capsules or gelatinous egg masses is a common phenomenon among many marine invertebrate. The structure and composition of egg masses varies among opisthobranch. Capsulated egg masses are found in the neritoposina and some caenogastropda, and gelatinous egg masses are found in the heterobranchia (Przeslawski, 2004). The fertilized eggs of the aplysiid are packaged in capsules that are embedded in layers of mucopolysaccharide jelly to form a cylindrical string called an egg masses. The egg masses of the aplysiid species is quite similar in shape and structure, but the number of capsules per unit length of egg masses and the number of eggs per capsule vary among aplysiid species. There exists an inverse relationship between the size of the eggs and the number of eggs per capsule (Bridges, 1975), but the relationship is not clear for many species that have smaller eggs. Also, among A. californica (Kriegstein et al., 1974; Capo et al., 2002), A. brasiliana and Bursatella leachii plei (Paige, 1986), the number of eggs per capsule was increase with increasing body size of animal. In this study, the number of eggs per capsule in case of A. kurodai collected from nature (400-700 g body weight) was approximately 15-25 eggs, while the number of eggs of $A$. kurodai in laboratory culture (from hatching to attainment of repro-ductive maturity, $4 \mathrm{~g}$ body weight) was 1-5 eggs. These results suggested that the number of eggs per capsule depended on the size of animal and was species specific.

Most mollusks undergo spiral holoblastic cleavage, and embryonic development varies by temperature and the egg size. In opisthobranchs, the egg diameter correlates positively with the size of the hatched veliger larvae, and hatching size also increases with increasing embryonic duration (Hadfield \& Switzer-Dunlap, 1984). In a study of the development of four aplysiid species, it was observed that at the same temperature, the embryonic periods are shorter among species with smaller eggs and longer among species with larger eggs (Switzer-Dunlap \& Hadfield, 1977). Although the exact developmental period from egg laying to hatching varies among aplysiid species, its range does not vary among species, i.e., it is generally $<16$ days. In the case of $A$. kurodai species, the fertilized eggs, like those of other mollusk, underwent spiral cleavage, but with unequal cell division. The eggs hatched at 10 days after spawning, within the range of other aplysiids.

\section{ACKNOWLEDGMENT}

This work was supported by National Research Foundation of Korea Grant funded by the Korean Government [NRF- 
2009-352-F00026].

\section{REFERENCES}

Beeman RD (1968) The order Anaspidea. The Veliger 3(Suppl.):87-102.

Beeman RD (1970) The anatomy and functional morphology of the reproductive system in the opisthobanch mollusk Phyllaplysia taylori Dall, 1900. The veliger 13: 1-31.

Benkendorff K (1999) Molluscan resources: the past present and future value of molluscs. In: Ponder W \& Lunney D (eds.), The Other 99\%. The Conservation and Biodiversity of Invertebrates. The Royal Zoological Society of New South Wales. Sydney, NSW, pp 1-454.

Berry AJ, Purvis J, Radhakrishnan KV (1992) Reproductive system and spermatogenesis in the opithobranch gastropod Retusa obtusa (Montagu). J Moll Stud 58:357-367.

Blankenship JE, Rock MK, Robbins LC, Livingston CA, Lehman HK (1983) Aspects of copulatory behavior and peptide control of egg laying in Aplysia. Fed Proc Fed Am Soc Exp Biol 42:96-100.

Bridges CB (1975) Larval development of Phyllaplysia taylori Dall, with a discussion of development in the Anaspidea (Opistobranchiata: Anaspidea). Ophelia 14: 161-184.

Capo TS, Fiber LA, Stommes DL, Walsh PJ (2002) The effect of stocking density on growth rate and maturation time in laboratory-reared california sea hares. J Am Assoc Lab Anim Sci 41:18-23.

Carefoot TH (1987) Aplysia: Its biology and ecology. Oceanogr Mar Biol Annu Rev 25:167-284.

Eyster LS (1979) Reproduction and developmental variability in the opisthobranchs Tenellia pallida. Mar Biol 51: 133-140.

Eyster LS (1986) The embryonic capsules of nudibranch molluscs: literature review and new studies on albumen and capsule wall ultrastructure. Am Malacol Bull 4: 205-216.

Hadfield MG, Switzer-Dunlap M (1984) Opithobranchs. In: Tompa AS, Verdonk NH, Van Den Biggelarr JAM (eds.), The Mollusca, vol 7. Academic Press, New York, pp 209-350.

Kaang BK, Kandel ER, Grant SGN (1993) Activation of cAMP-reponsive genes by stimuli that produce longterm facilitation in Aplysia sensory neurons. Neuron 10: 427-435 .

Kandel ER (1979) Behavioral Biology of Aplysia. W.H. Freeman and Co., San Fransisco, pp 1-463.

Kempf SC (1981) Long-lived larvae of the gastropod Aplysia juliana: Do they disperse and metamorphose or just slowly fade away? Mar Ecol Prog Ser 6:61-65.

Klussmann-Kolb A (2004) Phylogeny of the Aphysiidae (Gastopoda, Opisthobranchia) with new aspects of the evolution of seahares. Zoologica Scripta 33:439-462.

Kress A, Schmekel L (1992) Structure of the female genital glands of the oviduct in the opithobranch mollusk, Runcina. Tissue Cell 24:95-110.

Kriegstein AR, Castellucci V, Kandel ER (1974) Metamorphosis of Aplysia californica in laboratory culture. Proc Nat Acad Sci USA 71:3654-3658.

Lalli CM, Conover RJ (1973) Reproduction and development of Paedoclione doliiformis, and a comparison with Clione limacine (Opisthobranchia : Gymnosomata). Mar Biol 19:13-22.

Lee CH, Kaang BK, Lee YD (2011) Gonadal development and reproductive cycle of sea hare Aplysia kurodai in Jeju coastal waters. Dev Reprod 15:257-263.

Leonard JL, Lukowiak K (1991) Sex and the simultaneous hermaphrodite: Testing models of male-female conflict in a sea slug, Navanax inermis (Opisthobranch). Anim Behav 41:255-266.

Paige J (1986) The laboratory culture of two aplysiids, Aplysia brasiliana Rang, 1828, and Bursatella leachii 
plei (Rang, 1828) (Gastropoda: Opisthobranchia) in artificial seawater. The Veliger 29:64-69.

Painter SD, Kalman VK, Nagle GT, Zuckerman RA, Blakenship JE (1985) The anatomy and functional morphology of the large hermaphroditic duct of three species of Aplysia, with special reference of the atrial gland. J Morphol 186:167-194.

Pawlings T (1999) Adaptations to physical stresses in the intertidal zone: the egg capsules of neogastropod molluscs. Amer Zool 39:230-243.

Plaut I (1993) Ecology and ecophysiology of the sea hare, Aplysia oculifera (Adams and Reeve, 1850) in the Gulf of Eilat (Aqaba). Ph. D. thesis, Hebrew University, Jerusalem (in Hebrew with English abstract).

Przeslawski R (2004) A review of the effects of environmental stress on embryonic development within intertidal gastropod egg masses. Moll Res 24:43-63.

Przeslawski R, Benkendorff K (2005) The role of surface fouling the development of encapsulated gastropod embryos. J Moll Stud 71:75-83.

Rivest BR (1984) Copulation by hypodermic injection in the nudibranchs Palio zosterae and P. dubia (Gastropoda, Opisthobranchia). Biol Bull 167:543-554.

Strenth NE, Blankenship JE (1991) Reproductive patterns and seasonal occurrence of the sea hare Aplysia brasiliana Rang (Gastropoda, Opithobranchia) at South Padre Island, Texas. Am Malac Bull 9:85-88.

Switzer-Dunlap M, Hadfield MG (1977) Observations on development, larval growth and metamorphosis of four species of aplysiidae (Gastropoda: Opisthobranchia) in laboratory culture. J Exp Mar Biol Ecol 29:245-261.

Yusa Y (1996) The effects of body size on mating features in a field population of the hearmaphroditic sea hare Aplysia kurodai Baba, 1937 (Gastropoda: Opisthobranch). J Moll Stud 62:381-386. 